УДК 342.55

DOI 10.18101/2304-4446-2020-3-7-11

\title{
О МЕРАХ ПО УКРЕПЛЕНИЮ КАДРОВОГО ПОТЕНЦИАЛА В ГОРОДСКОМ ОКРУГЕ Г. УЛАН-УДЭ
}

\section{(C) Аршолоева Оюна Хайдаповна}

кандидат социологических наук, доцент,

Бурятский государственный университет имени Доржи Банзарова

Россия, 670000, г. Улан-Удэ, ул. Смолина, 24а

E-mail: arsholoeva1975@mail.ru

Рост эффективности управления на муниципальном уровне, основанный на развитии кадрового потенциала, имеет ряд существенных ограничений. Основным фактором теперь становится не экстенсивный способ за счет простого увеличения числа муниципальных служащих, а прежде всего профессиональная переподготовка, включающая как повышение квалификации муниципальных служащих, так и их профессиональную переподготовку. В статье проведен анализ состояния кадрового потенциала городского округа «город Улан-Удэ». Автором предложены варианты успешного развития кадрового потенциала органов местного самоуправления на основе привлечения талантливых молодых специалистов на муниципальную службу. Инструментом для реализации данной стратегии может стать конкурс «Лидеры Улан-Удэ», который обеспечивает равные стартовые возможности всем участникам независимо от их места рождения, материального достатка, социального статуса, национальности и прочего.

Ключевые слова: муниципальная служба; местное самоуправление; кадры; муниципальные служащие; кадровая политика; кадровый потенциал; кадровый резерв.

\section{Для цитирования}

Аршолоева О. Х. О мерах по укреплению кадрового потенциала в городском округе г. Улан-Удэ // Вестник Бурятского государственного университета. Экономика и менеджмент. 2020. № 3. С. 7-11.

Кадровая политика представляет собой деятельность всех структурных подразделений по созданию целостной системы для формирования и эффективного использования трудовых ресурсов. Мероприятия по укреплению кадрового потенциала администрации г. Улан-Удэ ориентированы на эффективное решение актуальных социально-экономических задач для обеспечения комфортной среды проживания населения в нашем городе.

Основными направлениями организации работы по управлению кадрами в администрации г. Улан-Удэ являются:

- подбор, расстановка и воспитание профессиональных кадров;

- мотивация и стимулирование труда;

- повышение эффективности управленческого труда;

- профессиональное развитие кадров.

Также к специфичным вопросам государственно-муниципальной работы относятся:

- антикоррупционная деятельность;

- государственно-служебная культура. 
В администрации г. Улан-Удэ на 31 декабря 2019 г. общая численность муниципальных служащих составляет 537 чел., 89 чел. замещают должности, не относящиеся к муниципальной службе, в том числе 45 единиц за счет субвенций (из них 38 муниципальных служащих и 7 должностей, не относящихся к муниципальной службе), средний возраст работающих - 40 лет. В администрации г. Улан-Удэ насчитывается порядка 170 подведомственных учреждений образования, воспитания, физического воспитания, жилищно-коммунального комплекса с численностью работающих более 10 тыс.

Таблица 1

Кадровый состав городского округа «Город Улан-Удэ» в 2018-2019 гг.

\begin{tabular}{|c|c|c|}
\hline Показатель & 2018 & 2019 \\
\hline 1. Муниципальные должности & 9 & 9 \\
\hline 2. Должности муниципальной службы: & 475 & 541 \\
\hline высшие & 30 & 25 \\
\hline главные & 98 & 104 \\
\hline ведущие & 173 & 200 \\
\hline старшие & 174 & 210 \\
\hline младшие & 0 & 0 \\
\hline 3. Должности, не относящиеся к муниципальной службе & 93 & 90 \\
\hline 4. Другой персонал, состоящий в штате & - & - \\
\hline $\begin{array}{l}\text { 5. Численность выбывших работников за год (муници- } \\
\text { пальный служащий/другой персонал) }\end{array}$ & 45 & 112 \\
\hline $\begin{array}{l}\text { 6. Доля муниципальных служащих, имеющих высшее } \\
\text { образование, всего: }\end{array}$ & 475 & 541 \\
\hline В т. Ч. соответствующее профилю деятельности & 457 & 527 \\
\hline В т. ч. управленческое образование & 84 & 100 \\
\hline
\end{tabular}

В целях обеспечения участия г. Улан-Удэ во всех национальных проектах, программах поддержки Минвостокразвития РФ, госпрограммах РФ и решения проблем развития общественного транспорта, повышения эффективности в сфере предоставления транспортных услуг населению, организации дорожного движения, транспортного обслуживания, обеспечения безопасности дорожного движения произошло увеличение численности муниципальных служащих.

В 2018-2019 гг. наблюдалось интенсивное развитие системы подготовки, переподготовки, повышения квалификации муниципальных служащих. Большое значение для непрерывного профессионального образования имело 50\%-ное субсидирование целевых муниципальных программ повышения квалификации со стороны Республики Бурятия. Особого внимания в связи с утверждением справочника квалификационных требований к специальностям требуют направления подготовки, знания и умения, которые необходимы для замещения должностей государственной гражданской службы с учетом области и вида профессиональной служебной деятельности государственных гражданских служащих.

Профессиональную переподготовку муниципальные служащие проходят по таким основным специальностям, как: 
О. Х. Аршолоева. О мерах по укреплению кадрового потенциала в городском округе г. Улан-Удэ

- «Государственное и муниципальное управление»;

- «Управление персоналом»;

- «Юриспруденция»;

- «Бухгалтерский учет»;

- «Педагогика и психология»;

- «Контрактная система в сфере закупок.

Таблица 2

Профессиональное обучение муниципальных служащих

\begin{tabular}{|l|c|c|}
\hline & $\mathbf{2 0 1 8}$ & 2019 \\
\hline $\begin{array}{l}\text { Курсы повышения квалификации } \\
\text { по актуальным направлениям }\end{array}$ & 401 & 354 \\
\hline Профессиональная переподготовка & $\mathbf{5 4}$ & $\mathbf{5 9}$ \\
\hline
\end{tabular}

Сегодня в органах местного самоуправления города сохраняется тенденция дефицита высококвалифицированных кадров. Ни для кого не секрет, что основной мотивацией является финансовая сторона, в связи с чем высококвалифицированные специалисты уходят в другие сферы.

При анализе исполнения законодательства о муниципальной службе в Республике Бурятия выявлены типичные проблемы:

- недостаточные социальные гарантии и меры социальной защиты муниципальных служащих;

- невысокий престиж муниципальной службы;

- возложение дополнительных обязанностей в рамках антикоррупционного законодательства;

- низкий уровень оплаты труда муниципальных служащих, особенно в нижнем и среднем звеньях управления;

- отсутствие преемственности (взаимосвязи) кадрового резерва государственной и муниципальной службы в части возможности назначений из резерва иного уровня публичной власти.

Таблица 3

Управленческий резерв кадров

\begin{tabular}{|l|c|c|c|c|c|}
\hline & 2015 & 2016 & 2017 & 2018 & 2019 \\
\hline Назначено из резерва: & 34 & 69 & 61 & 26 & 60 \\
\hline высшая & 4 & 1 & 0 & 0 & 0 \\
\hline главная & 2 & 18 & 13 & 1 & 7 \\
\hline ведущая & 8 & 18 & 14 & 6 & 15 \\
\hline старшая & 20 & 32 & 34 & 19 & 38 \\
\hline
\end{tabular}

Формирование кадрового резерва и его эффективное использование - актуальное направление кадровой политики, реализуемое в целях повышения профессионализма кадрового состава муниципальной службы. 
По состоянию на 31 декабря 2019 г. в муниципальный кадровый резерв городского округа «Город Улан-Удэ» входит 201 человек, в том числе 52 чел. в резерве управленческих кадров, что составляет $25 \%$ общего количества резервистов. Всего 60 человек назначено из резерва на должности муниципальной службы за 2019 г. За весь период с 2015 по 2019 г. назначено из резерва на должности муниципальной службы 241 человек.

В современных условиях важным вопросом кадровой политики России является профессионализм управленческих кадров. Отсюда возникает необходимость повышения уровня их профессиональной подготовки. Общество нуждается профессионалах, способных решать задачи любой сложности.

Спрос на талантливых людей был, есть и будет всегда. Ведь именно они выступают катализаторами развития в сферах государственного, хозяйственного, финансового, корпоративного управления. Для укрепления кадрового потенциала г. УланУдэ большое значение имеют подбор и расстановка кадров руководителей.

В эпоху стремительного научно-технического прогресса, быстрых и глубоких перемен во всех областях жизни выявление, выдвижение управленческих талантов становится насущной потребностью общества. От того, насколько успешна эта работа, прямо зависит жизнеспособность города, региона, страны.

Сегодня в повестке города - прорыв на качественно новые рубежи технологического, экономического, социального развития. Для этого необходимы дальнейшие действия по совершенствованию управления городом. В целом по стране уже прокатилась волна конкурса «Лидеры России», в результате - приглашение и назначение на высокие посты и должности.

Необходимо привлечь в государственно-муниципальное управление города людей, обладающих сильным интеллектом, должным профессионализмом, творческими способностями, умением использовать современные цифровые инструменты, имеющих нравственные и духовные личностные качества, умеющих поддерживать постоянный диалог с людьми, не только слушать, но и слышать их, выполнять данные обещания.

В г. Улан-Удэ с июня по сентябрь 2019 г. был проведен открытый кадровый конкурс «Лидеры Улан-Удэ». Данный проект был направлен на поиск, развитие и поддержку перспективных лиц, обладающих высоким уровнем деловых и лидерских качеств, управленческих компетенций. Для участников проекта была уникальная возможность заявить о себе, проверить себя, получить оценку экспертов, коллег, наставников проекта, усилить свои лидерские навыки.

В конкурсе приняло участие более 600 молодых специалистов. По результатам дистанционного тестирования 100 человек стали участниками полуфинала. 10 августа 2019 г. прошел полуфинал конкурса «Лидеры Улан-У дэ», в ходе которого конкурсанты решали «кейсовые» задачи. Победителями полуфинала (группового отбора) стали 36 участников, имеющих наиболее высокие значения индивидуального рейтинга. 4 сентября 2019 г. прошел заключительный четвертый этап - финал конкурса в форме защиты индивидуальных проектов. На трех площадках (экономика, инфраструктура, социальная сфера) финалисты представляли свои работы. 10 участников проекта стали победителями открытого кадрового конкурса «Лидеры Улан-Удэ» и получили сертификат для прохождения образовательной программы MINI MBA. 
Предназначение проекта «Лидеры Улан-Удэ» - выявлять таких людей, держать их в поле зрения, помогать в реализации своего потенциала с наибольшей пользой для города. Конкурс обеспечивает равные стартовые возможности всем участникам независимо от их места рождения, материального достатка, социального статуса, национальности и прочего.

В сложных социально-экономических условиях кадровая стратегия администрации г. Улан-Удэ по привлечению талантливых молодых специалистов на муниципальную службу может стать стратегией успеха. Бизнес и власть, работая совместно, смогут стать фундаментом для формирования компетентных профессионалов, способных обеспечить инновационное внедрение современных технологий на муниципальной службе.

\section{Литература}

1. Дугарова А. А., Санжин Б. Б., Шаралдаева А. Б. Государственная политика по формированию кадрового резерва органов местного самоуправления Республики Бурятия: проблемы и перспективы // Известия Юго-Западного государственного университета. Сер. Экономика. Социология. Менеджмент. 2016. № 4(21). С. 31-41.

2. Елбаева Д. В., Аршолоева О. Х., Гончикова М. Д. Формирование, подготовка и использование резерва управленческих кадров в Администрации г. Улан-Удэ // Экономика и предпринимательство. 2016. № 12-4(77). С. 256-258.

3. Цыренов Д. Д. Оценка качества профессионального образования с учетом критерия занятости: теория и практика // Проблемы современной экономики. 2011. № 3(39). C. $315-318$.

4. Цыренов Д. Д. Экономика знаний в Республике Бурятия: факторный анализ // Вестник Бурятского государственного университета. 2013. № 2. С. 25-27.

\section{ON THE WORKFORCE CAPACITY MEASURES IN ULAN-UDE URBAN DISTRICT}

Oyuna Kh. Arsholoeva

Cand. Sci. (Sociol.), A/Prof.,

Dorzhi Banzarov Buryat State University

24a Smolina St., Ulan-Ude 670000, Russia

E-mail: arsholoeva1975@mail.ru

Increase of management efficiency at the municipal level based on human resource development has a number of meaningful constraints. Therefore the key determinant is not an extensive method by simply increasing the number of municipal employees, but, above all, professional retraining, including both advanced training of municipal servants and their professional retraining. The article analyzes the state of workforce capacity in Ulan-Ude urban district. We give some proposals for the successful development of workforce capacity of local self-government bodies by attracting talented young specialists to municipal service. Ulan-Ude Leaders competition can become a tool for the implementation of this strategy by provision of equal starting opportunities for all participants, regardless of their place of birth, material wealth, social status, nationality.

Keywords: municipal service; local government; staff; municipal servants; personnel policy; workforce capacity; personnel reserve. 